I denne læsers øjne gør det en forskel i receptionen af Karen Blixen, både som forfatter og som menneske, at faktuelle oplysninger som disse lægges frem. At Denys så kort og kontant afviste et faderskab, når han vidste, hvor brændende Karen Blixen ønskede sig et barn, at han ikke gik ind for kvinders stemmeret - det bidrager alt sammen til et mere nuanceret og komplekst portræt af Denys Finch Hatton, hvor der ofte har været en tendens til, muligvis foranlediget af Karens egen tekster (og Robert Redfords portræt af ham i filmen "Out of Africa" fra 1985), at opfatte ham udelukkende som en charmerende engelsk Eton-uddannet gentleman, der reciterede Shakespeare og lyttede til Wagner. Charmerende gentleman, javist, men han var også så meget andet.

Løvinden er en rigtig god bog, hvorunder der ligger et kæmpe stort stykke historisk research. Også billedsiden er berigende, med flere hidtil ukendte billeder af Karen Blixen. Hun ser allermest glad ud på de billeder, hvor hun er på sin farm, omgivet af dyr, mennesker og kaffeplanter.

Titlen er velvalgt, fordi den symboliserer en kvinde der kæmpede det bedste hun havde lært for at holde sammen på sin farm og sit kærlighedsforhold. Bogen gjorde mig klogere og gav mig et nyt og mere positivt syn på Karen Blixen. Efter endt læsning var jeg ikke ét sekund i tvivl om, at Karen Blixen blev en fri og emanciperet kvinde i Afrika, da hun tog kaffefarmens overlevelse på sig. Karen Blixen "opslog sin ridderhjelm" i Afrika, skjulte sig ikke, men stod ved den hun var. Gamle Ingemann havde ret; der er forskel på det liv, vi lever i fordækthed, og det liv vi kan leve, når vi står ved dem, vi er.

Anmeldt af Lone Kølle Martinsen

\title{
Den leende og legende Blixen
}

Charlotte Engberg: Latter og lettere beruset. Om at læse Karen Blixen, Syddansk Univsersitetsforlag, 2019.

Karen Blixen efterlyste flere gange i sit liv legekammerater med sans for det, hun kaldte fun. Det uoversættelige ord var for hende forbundet med fandenivoldsk latter, intens livsfølelse, lidenskabeligt mod og dødsforagt, med humor, ironi, leg, munterhed og ikke mindst med indbildningskraft og fortællelyst eller med Goethes formulering Lust zu fabulieren. I litteraturforskeren Charlotte Engberg har Blixen omsider fundet en læser, der tager hendes begreb om fun alvorligt, ikke som nøgle til forståelse af hendes væsen, selv om det også kunne være muligt, men som et velegnet begreb til at indkredse en bestemt kvalitet ved Blixens fortællinger og ved selve hendes måde at konstruere en fortælling på. Og det er netop gennem opmærksomheden på latteren i Blixens tekster - og derudover også gennem en række øjenåbnende perspektiveringer til billedkunsten - at Engberg bringer nye indsigter frem i sin eminente udgivelse med den besnærende titel Latter og lettere beruset. Om at læse Karen Blixen. 
Engberg fokuserer på netop fortællingerne og lægger afstand til den biografiske indfaldsvinkel til Blixens forfatterskab, og det er en befrielse netop i disse år - hvor der er en, om muligt, forstærket interesse for Blixens liv og levned - at hendes udgivelse består af en række vidende og fintmærkende nærlæsninger, der stort set er løsrevet fra det biografiske stof.

Engberg går ikke kronologisk frem, men laver et tværsnit gennem forfatterskabet og foretager ni nærlæsninger med hovedvægten på fortællinger fra Sidste Fortællinger og Syv Fantastiske Fortællinger med det formål at tegne "den samlede signatur" - eller poetik om man vil - der træder frem, når man bevæger sig rundt i Blixens fortællinger. Udgivelsen rummer også en læsning af Den afrikanske farm og i forlængelse heraf et perspektiverende kapitel om "Fortælleren som emigrant".

Engbergs udførlige analyser er bogen igennem ledsaget af en række billeder som på kongenial vis perspektiverer læsningerne. Bogens delikate og smukt udførte billedspor ruller 24 meget forskellige malerier ud, spændende fra Caravaggios "Kortspillerne" fra ca. 1595 over guldaldermalerier (Lundbye, Melbye) til den amerikanske filmskaber og montage-og collagekunstner Joseph Cornell. Sidstnævntes Uden titel (Medici Prinsesse) fra ca. 1948 indleder Engbergs udgivelse som en slags forståelsesramme for Blixens metode og hendes fortællingers karakter af montager og kinesiske æsker sat sammen af motiver fra fortiden, af højt og lavt, lån fra billedkunsten og af både skjulte og direkte citater i "et slags Wunderkammer i analogi til Cornells bokse", som Engberg skriver. Udgivelsens delikate billedspor tjener flere formål. Det skaber et større forståelsesrum for Blixens metode og giver en ide om, hvor omfattende en kunst- og kulturhistorisk referenceramme, hun trækker på. Samtidig stimulerer billedserien på bedste performative vis læseren til yderligere analyse og perspektivering. Billedsporet peger også på den store inspiration, som Blixen henter i malerkunsten, når hun beskriver. Her forfølger og videreudvikler Engberg et markant spor fra sin udgivelse Billedets ekko (2000), hvor hun viser, hvor stor betydning det har for Blixens fortællestrategi, at hun var maler før hun blev forfatter. Fortællingerne får karakter af litterære stilleben - eller litterære dagguerreotypier, efter den tidlige billedkunst, som Blixen kredser om i et af sine essays. Understregningen af malerkunstens tydelige aftryk i Blixens beskrivelsesmåde afspejles i Engbergs sprog: "teksterne henter bl.a. deres suggestive kraft gennem med få sikre penselstrøg at male en scene op, et tableauagtigt sceneri".

I opsporingen og fremlæsningen af Blixens "samlede signatur" og hendes fortællingers særlige kendetegn er der nogle begreber, der går igen. Afgørende er Engbergs opfattelse af Blixen som en charlatan, en trickster, der på bedragerisk og anarkistisk vis vender op og ned på en række kulturelt overleverede og hævdvundne forestillinger. Engberg trækker på betydningen af en charlatan som en maskeklædt, omrejsende person, der med tungefærdighed, charmende snak og vrøvl faldbyder tvivlsomme varer, især lægemidler, med løfte om helbredelse. Engberg fremhæver, at Blixens selv omtalte Syv fantastiske Fortællinger som en "Vrøvlebog", og hun citerer fra "Syndfloden over Norderney" (Syv fantastiske Fortællinger), der på mange måder ses som emblematisk for Blixens "samlede signatur": "Torden og Lynild, Nymaanen, en Nattergal, en ung Pige; - alt dette er jo en Charlatans Effekter, - him- 
melske Charlatanerier, ligesom Spejlgalleriet i Versailles er det her paa Jorden". Engberg ser Blixens fortællinger som sådanne "charlatanerier", som udfoldelser af fun med genkommende elementer af gotisk-romantiske og melodramatiske effekter og med fokus på maskepi, forførelse, forklædning og identitet. Som de vigtigste reference- og identitetsfigurer udpeges Sheherazade og kaliffen Harun al Rashid/ Albondocan fra Tusind og én Nats Eventyr, fra hvem Blixen låner guddommelig indbildningskraft, list og evne til at fortrylle sit stof og sine omgivelser. Blixen lover ikke helbredelse som de omrejsende intrigemagere og gøglere, men Engberg betoner, at hendes fortællekunst kan opfattes og opleves som en kur mod kedsomhed og en lindring og opløftelse i den moderne tid, som Blixen så som affortryllet. Desuden peges på en dobbeltgestus i Blixens måde at fortælle på. På den ene side finder vi en legesyg gestus, hvor en klassisk fortælletradition genoplades og på den anden side en vemodig gestus, hvor denne tradition rives fra hinanden og fortællingen er under påvirkning fra ny litteratur. Engberg opfatter helt grundlæggende Blixen som en modernistisk forfatter, der skaber "nye historier af gamle".

Kunstneren som charlatan fremlæses fx i "Kardinalens første historie" (Sidste fortællinger), hvor kardinalen, der fortæller historien, viser sig som en ustabil og spaltet identitet og fortæller, som ikke indfrier sit løfte om at svare på fortællingens indledende spørgsmål: "Hvem er De?".

I sin fornemme analyse af Den afrikanske farm viser Engberg blandt meget andet, hvor frugtbart det kan være at distancere sig fra en biografisk vinkel og i stedet rette blikket mod værkets form og dets væv af intertekstuelle referencer. Adskillige biografisk orienterede forskere har undret sig over og fors $\emptyset \mathrm{gt}$ at forklare den påfaldende "upersonlige" måde, Blixen omgås sine egne forhold med. Hvorfor nævner hun kun sin svenske ægtemand en enkelt gang langt inde i værket? Er det, fordi hun er tavs om det, som gør allermest ondt? Hvorfor nævner hun slet ikke sin onkel, Aage Westenholz, der finansierede Farmen gennem 17 år? Var det for at hævne sig på ham? Engberg har et interessant tekstnært bud, idet hun knytter Den afrikanske farm, og i samme åndedrag også "Kardinalens første historie", sammen med den klassiske fortælling, særligt Homers Iliade og Odyssee, og også Vergils Aneide og disse værkers netop "upersonlige" fortællemåde, deres versemål og rytme. Her som andre steder i sine analyser benytter Engberg Det Danske Sprog- og Litteraturselskabs videnskabelige udgave af Blixens værker, og disse værkers udførlige og omfattende tekstkommentarer er en foræring i forhold til at vise og udnytte, hvor rigt et resonansrum af referencer, der omgiver Blixens fortællinger.

En af de få gange, hvor Engberg inddrager biografisk stof i form af brevmateriale, citerer hun fra et brev til Thomas Dinesen fra 1931, hvor Blixen betoner, at overblik er noget af det vigtigste at stræbe efter i livet: "I jo højere Grad man opnaar at faa Overblik, - som næsten er det vigtigste at stræbe efter i Livet, - jo mere gaar hele Tilværelsens Herlighed, og Mangfoldighed op for én". Her er selvfølgelig tale om et overblik af både eksistentiel og kunstfilosofisk art, en evne til at løfte sig over tilværelsens tilskikkelser og på behørig og nødvendig afstand ane en sammenhæng og blive i stand til at fortælle. Ordet overblik er også sigende for Engbergs bog. Hun har et imponerende overblik over Blixens tekster og er hele tiden undervejs i sine 
analyser i stand til at zoome ind på betydningsbærende detaljer og så zoome ud og vise, hvordan detaljer og lokale pointer i en given fortælling også er gældende andre steder i forfatterskabet.

Den leende og legende Blixen står stærkt frem i Engbergs udgivelse. Hun er strejfet tidligere i Blixen-forskningen, men aldrig på et så systematisk og veldokumenteret grundlag som hos Engberg. Det kunne dog have været interessant at indføje Blixens eneste egentlige roman, Gengældelsens Veje, i denne sammenhæng, for der er i allerhøjeste grad fun på færde i både form og indhold i dette pasticheværk fra 1944. Blixen fremhæver selv, at værket er skrevet for morskabs skyld som en "Spøg" og en "Fornøjelse" for at udholde følelsen af indespærring under 2. Verdenskrig. Hovedpersonen, den unge pige Zosine, kan ikke leve uden morskab og "kommers" og en nøglereplik fra hende lyder: "Alvorlige Folk skal ikke gaa for strengt i Rette med et Menneske, for hvad det finder paa at more sig med, naar det er lukket inde som en Fange, og ikke en Gang har Lov til at sige, at det er i Fængsel".

Afgørende nye indsigter bæres frem når Engberg påpeger Blixens fortrolighed med billedkunstneriske konventioner, og når hun fremhæver betydningsbærende referencer til kunsthistoriske begreber og perioder. "At læse Blixens fortællinger er som at gå igennem et stort billedgalleri”, skriver Engberg. En lignende fornemmelse har man, når man går igennem Engbergs smukke værk. Man bliver beruset og beriget undervejs og får lyst til at læse eller genlæse Blixens værker - og til at gå med på legen.

Anmeldt af Benedikte F. Rostbøll 